Article

\title{
Assessment of Sweet Sorghum-Based Ethanol Potential in China within the Water-Energy-Food Nexus Framework
}

\author{
Xiaoxi Yan ${ }^{1,2,+}$, Dong Jiang ${ }^{1,2,3,+} \mathbb{C}^{\mathbb{D}}$, Jingying Fu ${ }^{1,2, *}$ and Mengmeng Hao ${ }^{1,2}$ \\ 1 Institute of Geographical Sciences and Natural Resources Research, Chinese Academy of Sciences, \\ 11A Datun Road, Beijing 100101, China; yanxx.15s@igsnrr.ac.cn (X.Y.); jiangd@igsnrr.ac.cn (D.J.); \\ haomm.16b@igsnrr.ac.cn (M.H.) \\ 2 College of Resources and Environment, University of Chinese Academy of Sciences, No. 19A Yuquan Road, \\ Beijing 100049, China \\ 3 Key Laboratory of Carrying Capacity Assessment for Resource and Environment, Ministry of Land \& \\ Resources, Beijing 100101, China \\ * Correspondence: fujy@igsnrr.ac.cn; Tel.: +86-10-6488-9221 \\ + These authors contributed equally to this work.
}

Received: 30 January 2018; Accepted: 30 March 2018; Published: 2 April 2018

\begin{abstract}
As bio-ethanol is developing rapidly, its impacts on food security, water security and the environment begin to receive worldwide attention, especially within the Water-Energy-Food nexus framework. The aim of this study is to present an integrated method of assessing sweet sorghum-based ethanol potential in China in compliance with the Water-Energy-Food nexus principles. Life cycle assessment is coupled with the DSSAT (the Decision Support System for Agrotechnology Transfer) model and geographic information technology to evaluate the spatial distribution of water consumption, net energy gain and Greenhouse Gas emission reduction potentials of developing sweet sorghum-based ethanol on marginal lands instead of cultivated land in China. Marginal lands with high water stress are excluded from the results considering their unsuitability of developing sweet sorghum-based ethanol due to possible energy-water conflicts. The results show that the water consumption, net energy gain and Greenhouse Gas emission reduction of developing sweet sorghum-based ethanol in China are evaluated as 348.95 billion $\mathrm{m}^{3}, 182.62$ billion MJ, and 2.47 million $t$ carbon per year, respectively. Some regions such as Yunnan Province in south China should be given priority for sweet sorghum-based ethanol development, while Jilin Province and Heilongjiang Province need further studies and assessment.
\end{abstract}

Keywords: WEF nexus; the DSSAT model; life cycle assessment; water consumption; net energy gain potential; GHG emission reduction; fuel ethanol

\section{Introduction}

Energy shortage and climate change are two great challenges today. In December 2015, the Paris Agreement confirmed that the increase in the global average temperature should be held below $2{ }^{\circ} \mathrm{C}$, and that countries should dedicate greater efforts to limit the temperature increase to $1.5^{\circ} \mathrm{C}[1,2]$. However, it is estimated that the world has already been warmed up by $1.8^{\circ} \mathrm{F}$ (equivalent to $1{ }^{\circ} \mathrm{C}$ ) because of too much carbon dioxide emission since the start of the industrial revolution. Hence, the energy sector must be decarbonized to fulfill the temperature requirement confirmed by the Paris Agreement [3]. It is hoped that renewable energy will help to alleviate the energy crisis and prevent further climate change $[4,5]$. To achieve the temperature limit of $1.5^{\circ} \mathrm{C}$, various kinds of renewable energy, including wind energy, solar energy and biofuels, have been applied, and they are 
predicted to be a fast-growing energy source of the energy market in the next 30 years [3]. According to 2018 BP Energy Outlook, renewable energy would account for $40 \%$ of the primary energy increase by 2040 [6]. In the transport sector, the share of renewable energy would probably at least triple from $3.5 \%$ to $10 \%$ according to 2017 REN's Renewable Global Futures [3]. For the application of renewable energy in the transport sector, $100 \%$ liquid biofuels, such as bio-ethanol and bio-diesel, or biofuels blended with gasoline are the main entry points [3]. Therefore, developing biofuels must be considered as a significant kind of renewable energy.

Water, energy and food are fundamental natural resources needed to help achieve the social, economic and environmental goals of human beings [7,8]. There are complex interconnections among them, and it is predicted that the demand for fresh water, energy and food will increase significantly in the next 20 years due to urbanization, population growth, climate change, agricultural demand, and so on [9-11]. As a result, Water-Energy-Food nexus has received worldwide attention since the 2011 Bonn Conference [12,13]. Recent studies showed that inappropriate development planning of biofuels may cause conflicts with water and food [14]. Increased biofuel demand would push up water use, and the low water efficiency of developing bio-ethanol on the marginal lands could aggravate water consumption [15-17]. Besides, planting energy crops on the cultivated lands may improve energy supply, but it also results in less cultivated lands for food planting and causes risks to food security [18]. Under these circumstances, it is necessary to avoid biofuels' conflicts with water and food when assessing the potential of biofuels.

In China, biomass energy is regarded as a core of the transition of China's energy structure. According to the 13th Five-Year Plan for Biomass Energy of the People's Republic of China, annual average biofuel consumption in China should run up to six million tons by 2020 [19]. However, China faces great challenges of water stress and food security. As China has limited cultivated land resources and large population, the development of energy crops must follow the principles "not using the grain intended for food, and not occupying the lands intended for grain production". To avoid intensifying problems of water stress and food security, the potential of sweet sorghum-based ethanol in China is assessed in compliance with the Water-Energy-Food nexus principles in this study. As a representative of non-food feedstock, sweet sorghum is considered because of its optimized tolerance to abiotic stresses and high levels of sugar accumulation in its stalks [20-22]. In addition, energy-food conflicts are avoided by using marginal lands instead of cultivated lands in China as the original potential places for sweet sorghum-based ethanol development, and the potential energy-water interconnections are assessed by coupling life cycle assessment method with the DSSAT (the Decision Support System for Agrotechnology Transfer) model. Life cycle assessment method is a technique for evaluating the potential impacts of a product (or service) over the life cycle [23-25]. The DSSAT model, released by the International Benchmark Sites Network for Agrotechnological Transfer, offers several independent primary modules for crop growth and development simulation [26]. Compared with the GREET (Greenhouse gases, Regulated Emissions, and Energy use in Transportation) model, a full life-cycle model to evaluate energy and emission impacts of advanced and new transportation fuels developed by Argonne National Lab [27-29], the DSSAT model pays more attention to the growing process of energy crops, which offers more mechanical supports for water consumption and biomass estimation. Thus, life cycle assessment and DSSAT rather than GREET are applied in this study.

Therefore, the main objective of this study is to present an integrated method of assessing sweet sorghum-based ethanol potential in China in compliance with the Water-Energy-Food nexus principles by coupling life cycle assessment method with the DSSAT model and geographic information technology. 


\section{Materials and Methods}

\subsection{System Boundary Definition}

Life cycle assessment is a technique for evaluating the potential impacts of a product (or service). It consists of four steps: system boundary definition, life cycle inventory, impacts analysis, and interpretation of inventory and impact analysis in relation to the scope of the study [23-25].

In this study, the life cycle assessment method was used to evaluate the potential of sweet sorghum-based ethanol in China over its life cycle. The scope of the life cycle assessment was to analyze water consumption, GHG (Greenhouse Gas) emissions, and the net energy gain potential of sweet sorghum-based ethanol on marginal land in China, and the flowchart of system boundary of life cycle assessment is shown in Figure 1. The life cycle of sweet sorghum-based ethanol includes five stages: sweet sorghum planting and harvesting stage, sweet sorghum transport stage, ethanol production stage, ethanol transport and distribution stage, and ethanol combustion stage.

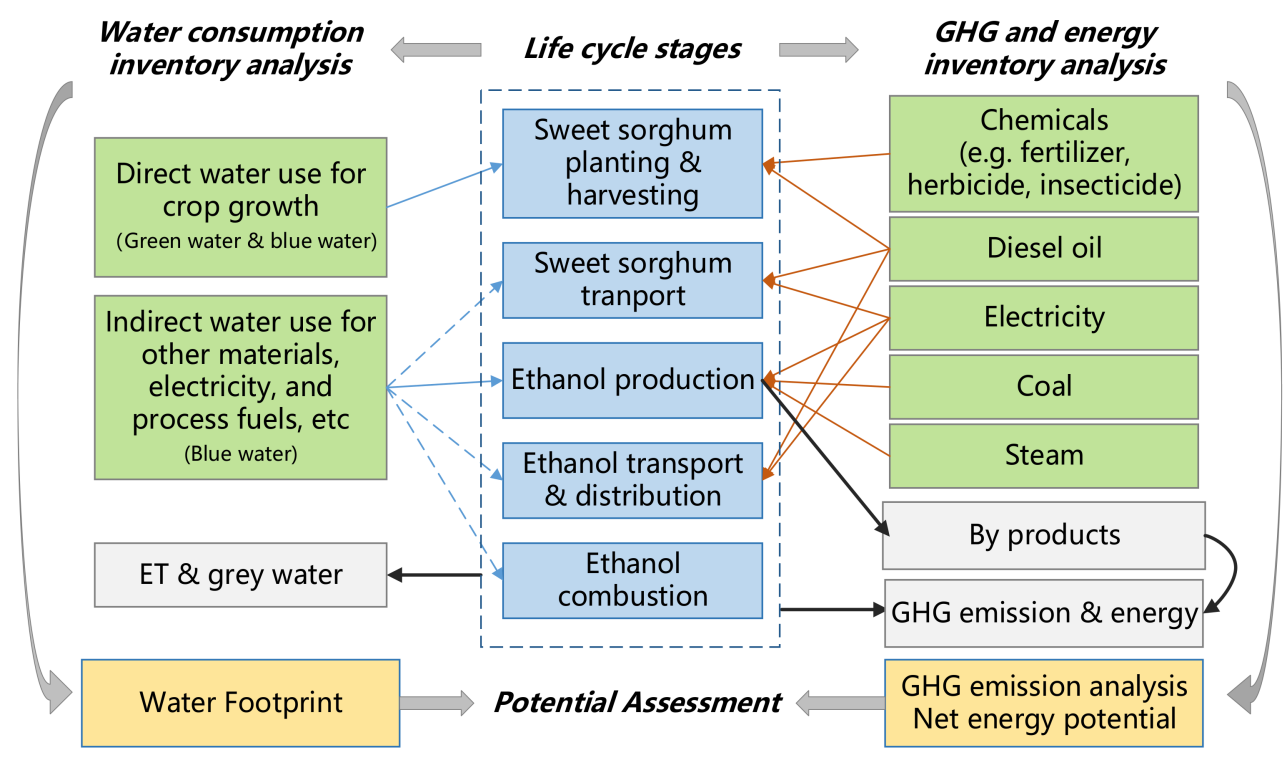

Figure 1. System boundary of life cycle assessment. Solid blue arrows show the input water flows that are considered, whereas dashed blue arrows show the input water flows that are not considered in this paper; brown arrows show the input flows of materials and energy; and black arrows show the output flows of water, GHG and energy.

The water consumption of every life cycle stage was analyzed, except for the two transport stages and the ethanol combustion stage because the quantity of water consumption in these three stages represented less than $1 \%$ of the total water consumption [16,17]. The GHG emissions and net energy gain were assessed by tracking the material and energy flow in all stages. Chemicals, diesel oil, electricity, and coal were considered as input materials in the inventory analysis of GHG emissions and the net energy assessment. The input and output materials were converted into equivalent carbon and energy to evaluate GHG emissions and the net energy gain potential.

\subsection{Biomass and ET (Evapotranspiration) Estimation by the DSSAT Model}

The DSSAT model comprises crop simulation models for over 42 crops (as of Version 4.7) as well as tools to facilitate effective use of the models [26]. The tools include database management programs for soil, weather, crop management and experimental data, utilities and application programs. The crop simulation models simulate growth, development and yield as a function of the soil-plant-atmosphere 
dynamics. In this paper, the DSSAT model was used for biomass and ET estimation at sweet sorghum planting and harvesting stages.

At the beginning, the DSSAT model was calibrated for biomass and ET simulation of the sweet sorghum crop by the field experimental data recorded by an energy crop cultivation company in Shandong Province. Then, the DSSAT model was set up to link with geospatial datasets for geo-spatial simulation. Non-geospatial datasets were arranged in text files, and geospatial datasets were organized using geographic information technology. Both geospatial datasets and non-geospatial datasets were integrated and called by the land unit module and then used by different primary modules for the simulation. As a result, the simulation results of biomass and ET were obtained. These results were then analyzed, using geographic information technology and life cycle assessment method, to obtain water consumption, net energy gain potential, and GHG emission results on a spatial scale. The flowchart of biomass and ET estimation by the DSSAT model is shown in Figure 2.

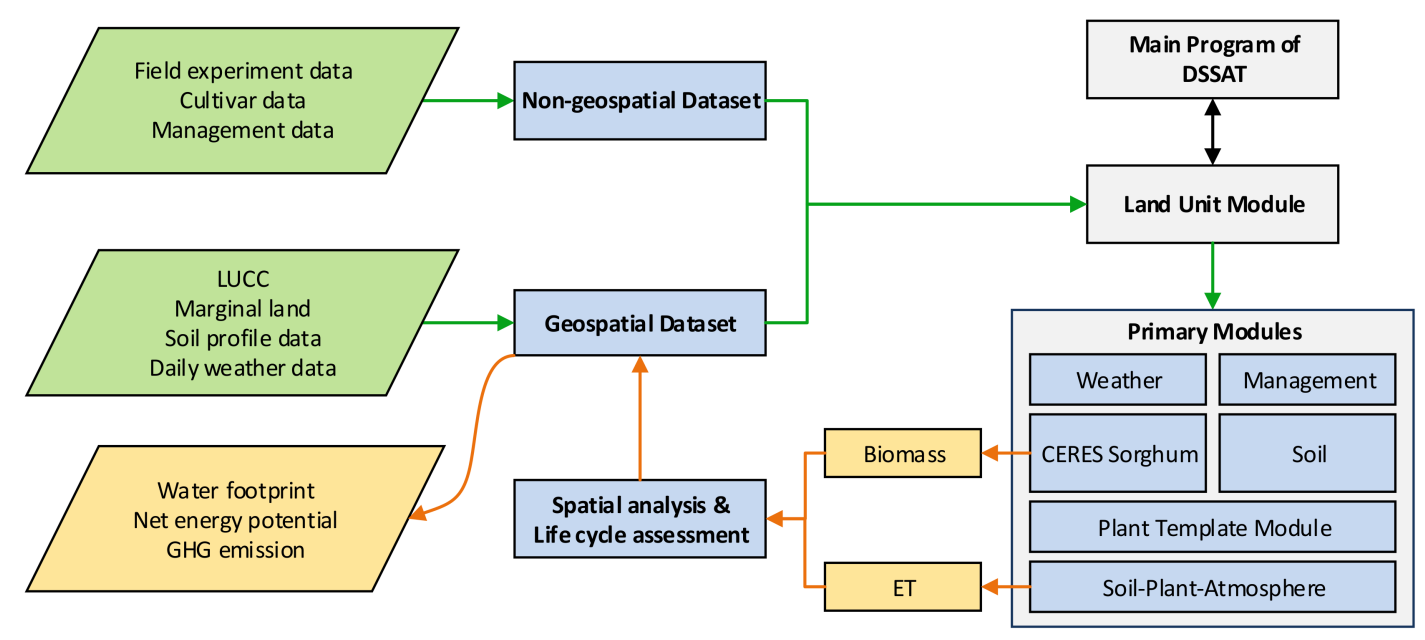

Figure 2. Flowchart of biomass and ET estimation by the DSSAT model. Green arrows indicate data flow of inputs, and orange arrows indicate data flow of outputs.

\subsection{Life Cycle Assessment}

\subsubsection{Water Consumption Assessment}

Based on the Water-Energy-Food nexus principles, a water consumption analysis of developing sweet sorghum-based ethanol on marginal lands in China is of great importance. This is because it reflects the complicated interactions between water resources and sweet sorghum development in China. As illustrated in Figure 1, water consumption at the planting and harvesting and ethanol production stages was considered to be the total water demand over the life cycle of sweet sorghum ethanol in this paper. The formula of total water consumption is as follows [16]:

$$
T W C=E T_{\text {actual }}+W C E
$$

where TWC (unit: $\mathrm{mm}$ ) is the Total Water Consumption of sweet sorghum-based ethanol over the life cycle; $E T_{\text {actual }}$ (unit: $\mathrm{mm}$ ) is the actual evapotranspiration at planting and harvesting stage; and WCE (unit: $\mathrm{mm}$ ) is the water consumption for ethanol production.

Actual evapotranspiration ( $\left.E T_{\text {actual }}\right)$ is composed of actual soil evaporation $\left(E T_{\text {soil }}\right)$ and plant transpiration $\left(E T_{\text {plant }}\right)[26,30]$. In this paper, $E T_{\text {actual }}$ was simulated using the DSSAT model (refer to Figure 2) which provides a separate module called the "soil-plant-atmosphere module" to simulate 
potential evapotranspiration (ET), actual soil evaporation $\left(E T_{\text {soil }}\right)$, and plant transpiration $\left(E T_{\text {plant }}\right)$. $E T_{\text {actual }}$ was calculated by the following formula.

$$
E T_{\text {actual }}=E T_{\text {soil }}+E T_{\text {plant }}
$$

Water demand for sweet sorghum-based ethanol production (WCE) was calculated based on the above-ground biomass of sweet sorghum at harvesting [16]. The formula is as follows:

$$
W C E=\frac{B \times E \times W}{10 * \rho}
$$

where $B$ (unit: $t \cdot h^{-1}$ ) is the above-ground biomass of sweet sorghum per hectare; $E$ (t ethanol $\cdot \mathrm{t}^{-1}$ biomass) is the conversion coefficient of converting biomass of sweet sorghum to fuel ethanol; $W$ (unit: $\mathrm{t}$ water $\cdot \mathrm{t}^{-1}$ ethanol) is water consumption for fuel ethanol production per unit ethanol; and $\rho$ is the water density with the value of $1.0 \mathrm{~g} \cdot \mathrm{cm}^{-3}$.

\subsubsection{Life Cycle Assessment of Net Energy Gain (NEG) Potential}

Net energy gain is defined as the difference between the energy input and output of a product or service [31,32]. The net energy gain of biofuel production in China depends highly on both the ethanol and the converting processes from energy crop to ethanol. In this paper, net energy gain was analyzed by tracking the energy flows of every life cycle stage.

The energy flow of sweet sorghum-based ethanol begins with solar energy (SE) as a significant energy input for sweet sorghum growing. Then, fossil energies (FE) are considered important energy inputs in every stage of the life cycle of sweet sorghum-based ethanol. Finally, biomass energy (BE) and a certain amount of fossil energy from by-products are produced and become the output energy of the sweet sorghum-based ethanol system. Only fossil energies were considered in the net energy gain assessment as solar energy is renewable energy. Net energy gain is defined as the summary of energy output minus the summary of fossil energy input, as the following formula [33].

$$
N E G=\left(B E+F E_{b y}-\sum_{i=2}^{4} F E_{i}\right) \times B-F E_{1} \times A_{\text {grid }}
$$

where NEG (unit: MJ.gird ${ }^{-1}$ ) is the net energy gain per grid; $B E$ (unit: $\mathrm{MJ} \cdot \mathrm{t}^{-1}$ ethanol) is energy output of ethanol combustion with a value of $29,660 \mathrm{MJ} / \mathrm{t}$ ethanol; $F E_{b y}$ (unit: $\mathrm{MJ} \cdot \mathrm{t}^{-1}$ ethanol) is fossil energy output from by-products; $F E_{1}$ (unit: $\mathrm{MJ} \cdot \mathrm{ha}^{-1}$ ) is the fossil energy input of the sweet sorghum planting and harvesting stage; $F E_{i}(i=2,3,4)$ (unit: MJ. $\mathrm{t}^{-1}$ ethanol) is the fossil energy inputs from the sweet sorghum transport stage, ethanol production stage, and ethanol transport and distribution stage, respectively; $B$ (unit: t. gird ${ }^{-1}$ ) is the above-ground biomass of sweet sorghum per grid; and $A_{\text {gird }}$ (unit: ha) is the area of each grid.

\subsubsection{Life Cycle Assessment of GHG Emission}

Greenhouse gases (GHG) are gases that cause the greenhouse effect [34]. The combustion of fossil fuels is considered a significant reason for the greenhouse effect, and fuel ethanol has been regarded as a potential fuel alternative to decrease GHG emissions. In this study, GHG emissions were analyzed based on the Carbon Balance Principle.

The Carbon Balance Principle is that the carbon dioxide in the atmosphere assimilated by crop will finally return to the atmosphere through fermentation for ethanol production, oxidation of residues, and combustion of ethanol, establishing a carbon balance. However, ideal circumstances do not exist, as extra materials and fossil fuels are put into the system to maintain the progress over the life cycle of fuel ethanol. Extra materials and fossil fuels bring about extra GHG emissions, breaking the carbon balance of ideal circumstances, and such GHG emissions were calculated in the assessment. 
GHG emissions are calculated by summarizing extra carbon release minus the avoided carbon release from by-products. The formula is as follows [32].

$$
C_{\text {total }}=C_{1} \times A_{\text {grid }}+B \times\left(\sum_{i=2}^{4} C_{i}-C_{\text {avoided }}\right)
$$

where $C_{\text {total }}$ (unit: $\mathrm{t}$ Carbon. grid $^{-1}$ ) is the total GHG emission of each grid; $C_{1}$ (unit: $\mathrm{t}$ Carbon $\cdot \mathrm{ha}^{-1}$ ) is GHG emissions of the sweet sorghum planting and harvesting stage; $C_{i}(i=2,3,4)$ (unit: $\mathrm{t}$ Carbon $\cdot \mathrm{t}^{-1}$ ethanol) is composed of the GHG emissions of sweet sorghum transport stage, ethanol production stage, and ethanol transport and distribution stage respectively; $C_{\text {avoided }}$ (unit: $\mathrm{t}$ Carbon $\cdot \mathrm{t}^{-1}$ ethanol) is the carbon emissions reduced by using by-products instead of external energy input; $A_{\text {gird }}$ (unit: ha) is the area of each grid; and $B$ (unit: $t \cdot$ gird $^{-1}$ ) is the above-ground biomass of sweet sorghum per grid.

Carbon emission reduction $\left(C_{\text {reduce }}\right)$ is used to evaluate how much carbon emission could be reduced by biofuel compared with the carbon emission of petrol with the same energy output. The equation is as follows.

$$
C_{\text {reduce }}=\frac{B \times B E \times W_{\text {petrol }}}{E \times 1000}-C_{\text {total }}
$$

where $C_{\text {reduce }}$ (unit: $\mathrm{t}$ carbon.grid ${ }^{-1}$ ) is the carbon emission reduction potential per grid; $B$ (unit: $\mathrm{t} \cdot$ gird $^{-1}$ ) is the above-ground biomass of sweet sorghum per grid; $B E$ (unit: MJ. $\mathrm{t}^{-1}$ ethanol) is the energy output of ethanol combustion with a value of $29,660 \mathrm{MJ} / \mathrm{t}$ ethanol; $W_{\text {petrol }}$ (unit: $t$ carbon $\cdot \mathrm{MJ}^{-1}$ ) is the conversion coefficient of the calorific value to petrol with the value of $0.0189 \mathrm{t}$ carbon $\cdot \mathrm{MJ}^{-1}$; $E$ ( $\mathrm{t}$ ethanol $\cdot \mathrm{t}^{-1}$ biomass) is the conversion coefficient of converting biomass of sweet sorghum to fuel ethanol; and $C_{\text {total }}$ (unit: $\mathrm{t}$ Carbon.grid ${ }^{-1}$ ) is the total GHG emission of each grid.

\subsection{Data Preparation}

The datasets were divided into geospatial datasets and non-geospatial datasets. Geospatial datasets consisted of spatial distributions of marginal land, weather conditions, and soil profile conditions in China. These datasets were prepared using geographic information technology and used by the DSSAT model as evidence of growing environment for crops. Non-geospatial datasets included datasets for the DSSAT model such as field experimental data for the DSSAT model calibration, crop species parameters and crop planting and management datasets, and datasets for life cycle assessment such as life cycle inventories for the assessment of water consumption, net energy gain and GHG emission.

\subsubsection{Geospatial Datasets}

In this paper, geospatial datasets consisted of datasets indicating where energy crops should be planted such as marginal land in China, and datasets for the DSSAT model. The geospatial data list is shown in Table 1. Lands with low agricultural productive capacity are considered marginal land, such as lands with poor water supply, poor soil quality, pollution, and terrain challenges $[33,35,36]$. In the DSSAT model, the most important datasets that indicate crop growing conditions were soil profile data and weather data [26,37]. Soil profile data were needed in soil water, nitrogen, phosphorus and root sections. The required daily weather variables are solar radiation $\left(\mathrm{MJ} \cdot \mathrm{m}^{-2} \cdot \mathrm{day}^{-1}\right)$, maximum temperature $\left({ }^{\circ} \mathrm{C}\right)$, minimum temperature $\left({ }^{\circ} \mathrm{C}\right)$, and rainfall $(\mathrm{mm})$. Other necessary weather variables for every site are mean annual temperature $\left({ }^{\circ} \mathrm{C}\right)$ and annual air temperature amplitude $\left({ }^{\circ} \mathrm{C}\right)$. The DSSAT model also allowed optional variables such as dew point temperature $\left({ }^{\circ} \mathrm{C}\right)$, photosynthetic active radiation $\left(\right.$ moles $\cdot \mathrm{m}^{-2} \cdot$ day $\left.^{-1}\right)$, and wind speed $\left(\mathrm{km} \cdot \mathrm{day}^{-1}\right)$. 
Table 1. Basic information of geospatial datasets.

\begin{tabular}{|c|c|c|c|}
\hline Dataset & Unit & $\begin{array}{c}\text { Spatial } \\
\text { Resolution }\end{array}$ & Data Source \\
\hline Marginal land & - & $1 \mathrm{~km} \times 1 \mathrm{~km}$ & $\begin{array}{l}\text { Derived from LUCC, weather data, soil data, and } \\
\text { DEM }\end{array}$ \\
\hline DEM & $\mathrm{m}$ & $90 \mathrm{~m} \times 90 \mathrm{~m}$ & NASA Shuttle Radar Topographic Mission (SRTM) ${ }^{1}$ \\
\hline $\begin{array}{l}\text { Daily maximum air } \\
\text { temperature }\end{array}$ & Degrees Celsius & $10 \mathrm{~km} \times 10 \mathrm{~km}$ & $\begin{array}{l}\text { Derived from station observation daily maximum air } \\
\text { temperature provided by the China Meteorological } \\
\text { Administration }{ }^{2} \text { using ANUSPLIN Vrsn } 4.3 \text { [38] }\end{array}$ \\
\hline $\begin{array}{l}\text { Daily minimum air } \\
\text { temperature }\end{array}$ & Degrees Celsius & $10 \mathrm{~km} \times 10 \mathrm{~km}$ & $\begin{array}{l}\text { Derived from station observation daily minimum air } \\
\text { temperature provided by the China Meteorological } \\
\text { Administration }{ }^{2} \text { using ANUSPLIN Vrsn } 4.3 \text { [38] }\end{array}$ \\
\hline Precipitation & $\mathrm{mm}$ & $10 \mathrm{~km} \times 10 \mathrm{~km}$ & $\begin{array}{l}\text { Derived from station observation precipitation } \\
\text { provided by the China Meteorological } \\
\text { Administration }{ }^{2} \text { using ANUSPLIN Vrsn } 4.3 \text { [38] }\end{array}$ \\
\hline Solar radiation & moles $\cdot \mathrm{m}^{-2} \cdot$ day $^{-1}$ & $10 \mathrm{~km} \times 10 \mathrm{~km}$ & $\begin{array}{l}\text { Derived from station observation solar radiation } \\
\text { data provided by the China Meteorological } \\
\text { Administration }{ }^{2} \text { using ANUSPLIN Vrsn } 4.3 \text { [38] }\end{array}$ \\
\hline $\begin{array}{l}\text { Mean annual } \\
\text { temperature }\end{array}$ & Degrees Celsius & $10 \mathrm{~km} \times 10 \mathrm{~km}$ & $\begin{array}{l}\text { Derived from daily mean air temperature provided } \\
\text { by the China Meteorological Administration }{ }^{2}\end{array}$ \\
\hline $\begin{array}{l}\text { Annual air } \\
\text { temperature } \\
\text { amplitude }\end{array}$ & Degrees Celsius & $10 \mathrm{~km} \times 10 \mathrm{~km}$ & $\begin{array}{l}\text { Derived from daily maximum and minimum air } \\
\text { temperature provided by the China Meteorological } \\
\text { Administration }^{2}\end{array}$ \\
\hline Soil profiles & - & $1 \mathrm{~km} \times 1 \mathrm{~km}$ & $\begin{array}{l}\text { The published GSDE (Global Soil Data Set for Earth } \\
\text { System Modeling) database named }\end{array}$ \\
\hline
\end{tabular}

\subsubsection{Non-Geospatial Datasets}

Non-geospatial datasets were required by the DSSAT model and the life cycle assessment. A list of the non-geospatial datasets is provided in Table 2. In the DSSAT model, crop cultivar coefficients that indicate sweet sorghum's cultivar type were required to simulate the growing processes of the crop. Field experiment data were recorded from farmland and other land type experiments, and the records were essential for model correction and calibration. In the life cycle assessment, inventories were necessary to evaluate water consumption, GHG emissions, and net energy gain (refer to Tables 3 and 4). These inventories should be analyzed at every stage of sweet sorghum-based ethanol production, from the crop planting, raw material transport, ethanol production, and ethanol transport, to ethanol combustion stage.

Table 2. Basic information of non-geospatial datasets.

\begin{tabular}{ll}
\hline \multicolumn{1}{c}{ Dataset } & \multicolumn{1}{c}{ Data Source } \\
\hline Field experiment data & Field experiment records \\
\hline Crop cultivar coefficients & $\begin{array}{l}\text { Calibrated using the GLUE (Generalized Likelihood Uncertainty } \\
\text { Estimation) method based on field experiment data }\end{array}$ \\
\hline Field management data & Literature and field experiment records \\
\hline Water consumption at ethanol production stage & Literature, investigation and survey records \\
\hline Gross water of every basin & Literature, statistical data \\
\hline Life cycle inventories of GHG emission & Literature, investigation and survey records \\
\hline Life cycle inventories of net energy gain & Literature, investigation and survey records \\
\hline
\end{tabular}


Table 3. Data for water consumption calculation at ethanol production stages.

\begin{tabular}{|c|c|c|}
\hline Data Item & Data & Unit \\
\hline Conversion coefficient (from sweet sorghum to fuel ethanol) & 16 [16] & - \\
\hline Water density & $1.0[16]$ & $\mathrm{g} \cdot \mathrm{cm}^{-3}$ \\
\hline Water consumption coefficient & $9.5[16]$ & $\mathrm{t}$ water $\cdot \mathrm{t}^{-1}$ ethanol \\
\hline
\end{tabular}

Table 4. Life cycle inventories of energy and GHG emissions.

\begin{tabular}{|c|c|c|c|}
\hline Stage & Energy $^{1}$ & GHG Emissions & Items \\
\hline $\begin{array}{l}\text { Sweet sorghum } \\
\text { planting stage }\end{array}$ & -15362.48 MJ/ha [31] & +145.58 kg C/ha [32] & $\begin{array}{l}\text { Nitrogen fertilizer, phosphate } \\
\text { fertilizer, potassium fertilizer, } \\
\text { herbicide, insecticide, diesel oil }\end{array}$ \\
\hline $\begin{array}{l}\text { Sweet sorghum } \\
\text { transport stage }\end{array}$ & -3106.75 MJ/t ethanol [31] & +59.84 kg C/t ethanol [32] & Diesel oil and electricity \\
\hline Ethanol production & $-36433.75 \mathrm{MJ} / \mathrm{t}$ ethanol [31] & $+522.73 \mathrm{~kg} \mathrm{C} / \mathrm{t}$ ethanol [32] & Electricity, coal, and steam \\
\hline By-products & $+17310.60 \mathrm{MJ} / \mathrm{t}[31]$ & $-106 \mathrm{~kg} \mathrm{C} / \mathrm{t}$ ethanol [32] & \\
\hline Ethanol transport & $-262.35 \mathrm{MJ} / \mathrm{t}$ ethanol [31] & $+5.68 \mathrm{~kg} \mathrm{C} / \mathrm{t}$ ethanol [32] & Diesel oil and electricity \\
\hline $\begin{array}{l}\text { Ethanol } \\
\text { combustion }\end{array}$ & +29660 MJ/t ethanol [31] & - & $\begin{array}{l}\text { Energy and GHG produced } \\
\text { directly by ethanol combustion }\end{array}$ \\
\hline
\end{tabular}

\section{Results}

\subsection{Biomass and ET Estimation Results}

Biomass and ET were estimated by the coupling of the DSSAT model and geographic information technology. The result of sweet sorghum biomass on the marginal lands in China is shown in Figure 3, and the result of ET is shown in Figure 4.

As illustrated in Figure 3, per unit sweet sorghum biomass varied greatly from $680 \mathrm{~kg} / \mathrm{ha}$ to $24,538 \mathrm{~kg} / \mathrm{ha}$ in different regions of China. Low biomass areas were mainly located in Xinjiang Uygur Autonomous Region and Inner Mongolia Autonomous Region. High biomass areas were centralized in the southern part of China. The main causes of the disparity might be temperature, precipitation, and soil conditions. According to Figure 4, ET of sweet sorghum growing ranged from $126.29 \mathrm{~mm}$ to $869.51 \mathrm{~mm}$. The spatial distribution of ET showed a similar pattern to biomass. 


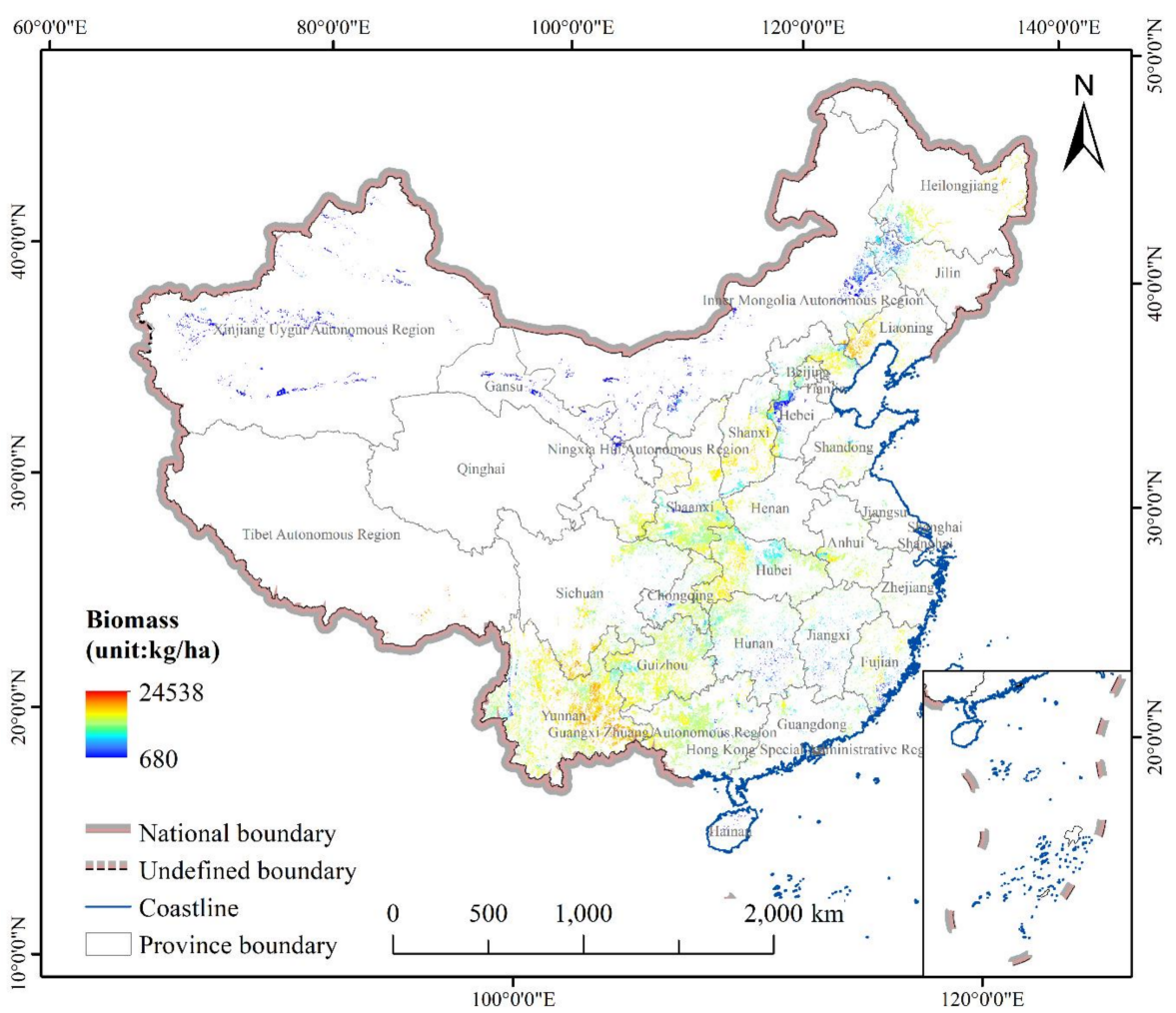

Figure 3. Spatial distribution of sweet sorghum biomass on the marginal lands in China.

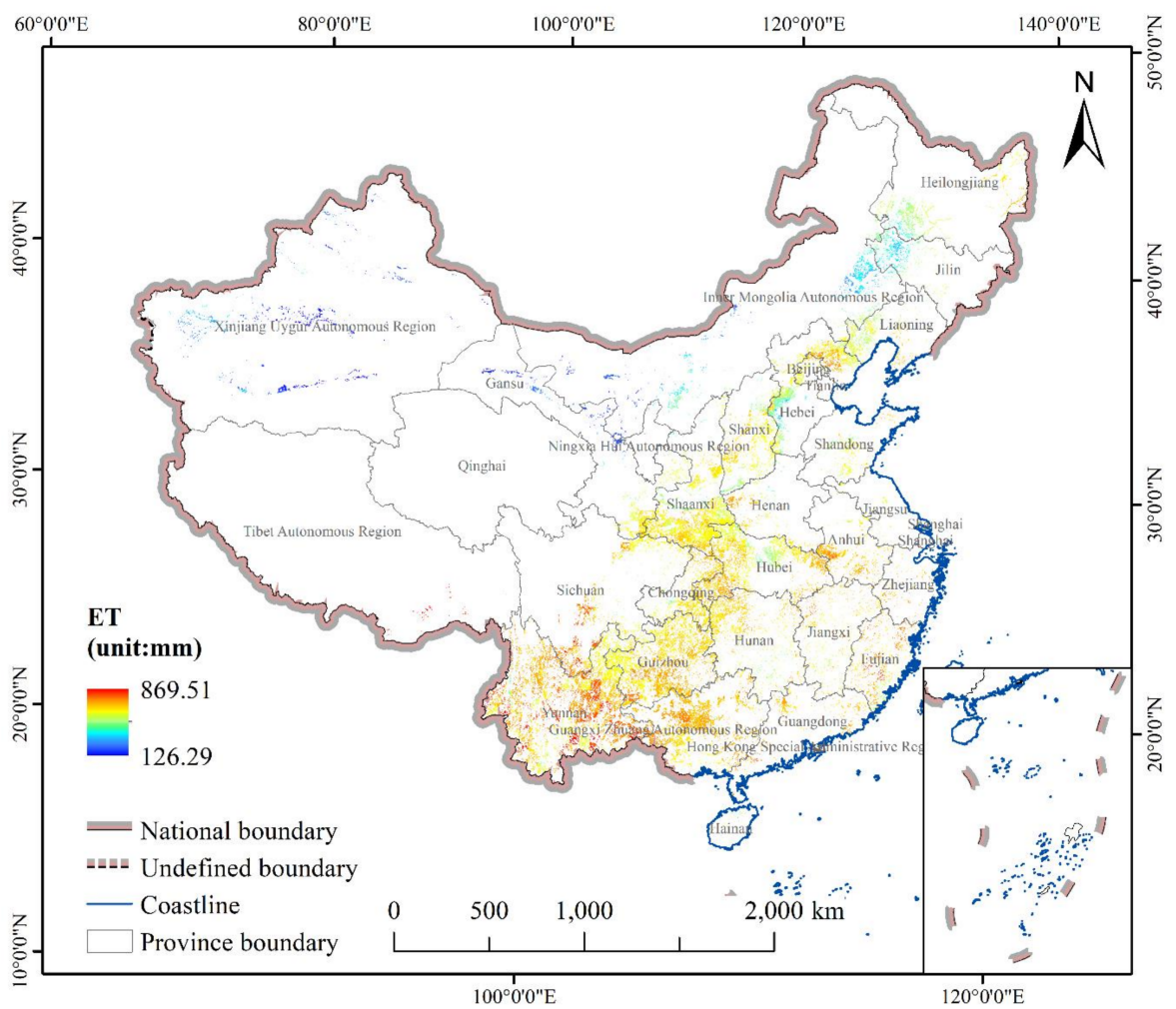

Figure 4. Spatial distribution of ET of sweet sorghum on the marginal lands in China. 


\subsection{Water Consumption Assessment Result}

In China, water is a necessity for the sustainable development of nature and human society. Regions threatened by water consumption of developing sweet sorghum on marginal lands were not considered suitable. In this section, the water consumption of fuel ethanol and other uses were compared relative to the water resources of basins in China. A drainage basin is an area of land around a large river with streams running down into it, which includes all the surface water from rain runoff, snowmelt, and nearby streams that run downslope towards the shared outlet, as well as the groundwater underneath the earth's surface. Therefore, comparing the water consumption with water resources at a basin scale accords with the water distribution patterns in nature.

The water consumption of fuel ethanol and pie charts of water consumption of every basin are shown in Figure 5. In Figure 5, the water requirements measured in millimeter are transformed to the volume of water consumption measured in million cubic meters.

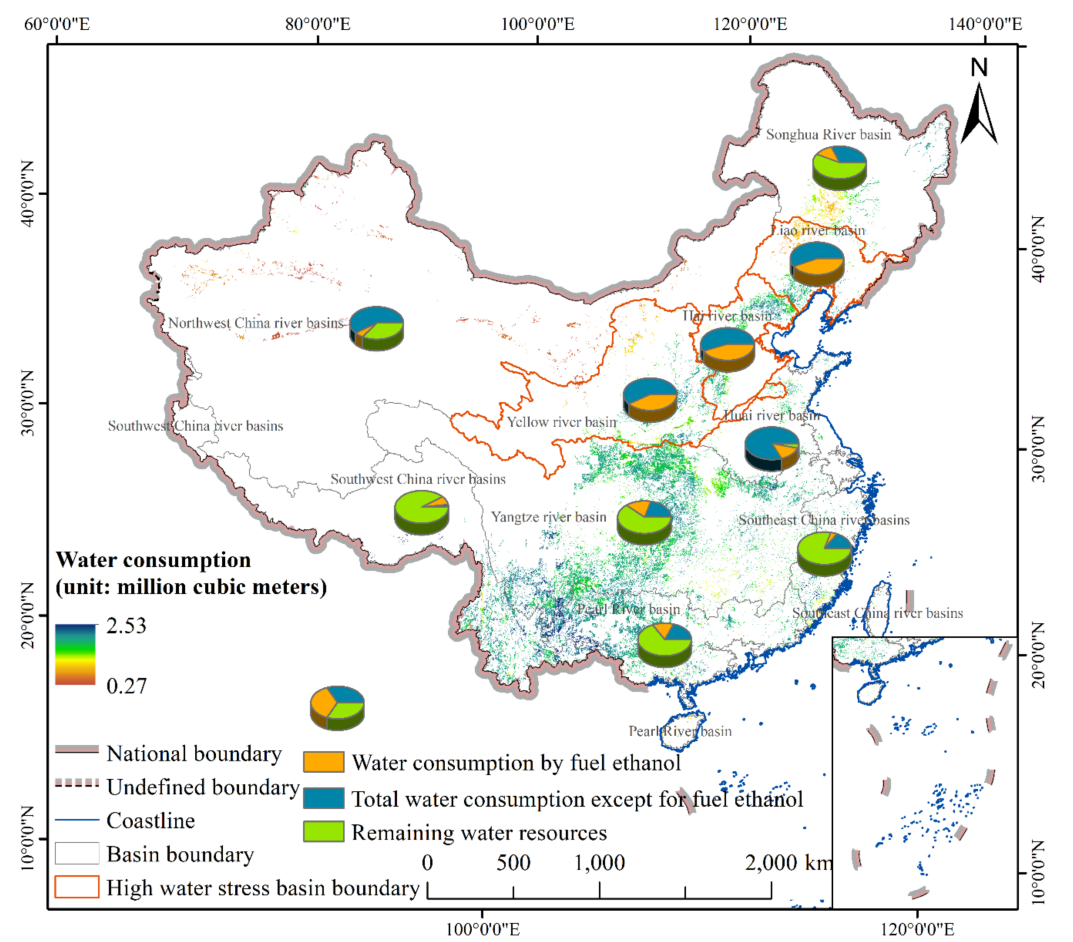

Figure 5. Water consumption of sweet sorghum-based ethanol and basin boundaries. The pie charts represent the total water resource in the regions: the orange polar areas represent water consumption by sweet sorghum-based ethanol; the blue polar areas represent total water consumption except for water consumption of developing sweet sorghum-based ethanol; and the green polar areas represent remaining water resources. Pie charts without a green polar area indicate that the basin would not have any water resources left for other uses if bio-ethanol were developed.

According to Figure 5, the water consumption of sweet sorghum-based ethanol development ranged widely from 0.27 million $\mathrm{m}^{3}$ to 2.53 million $\mathrm{m}^{3}$ per grid. High water consumption areas were centralized in the southern part of China, and the pie charts showed that after the regular use requirements and that from fuel ethanol, no water resources would remain in the Liao River, Hai River, and Yellow River basins to meet other water requirements. Overall, the total water consumption of fuel ethanol was 433.33 billion $\mathrm{m}^{3}$, including 69.80 billion $\mathrm{m}^{3}$ from the Liao River, Hai River, and Yellow River basins. 


\subsection{Net Energy Gain Assessment Result}

Net energy gain assessment is important because it shows how much energy could be achieved through developing sweet sorghum-based ethanol, and regions with high net energy gains are preferred. However, with the consideration of water stress, the Liao River, Hai River, and Yellow River basins were considered not suitable. As a result, only net energy gain on marginal lands without high water use stress was analyzed. The spatial distribution of the net energy gain is shown in Figure 6.

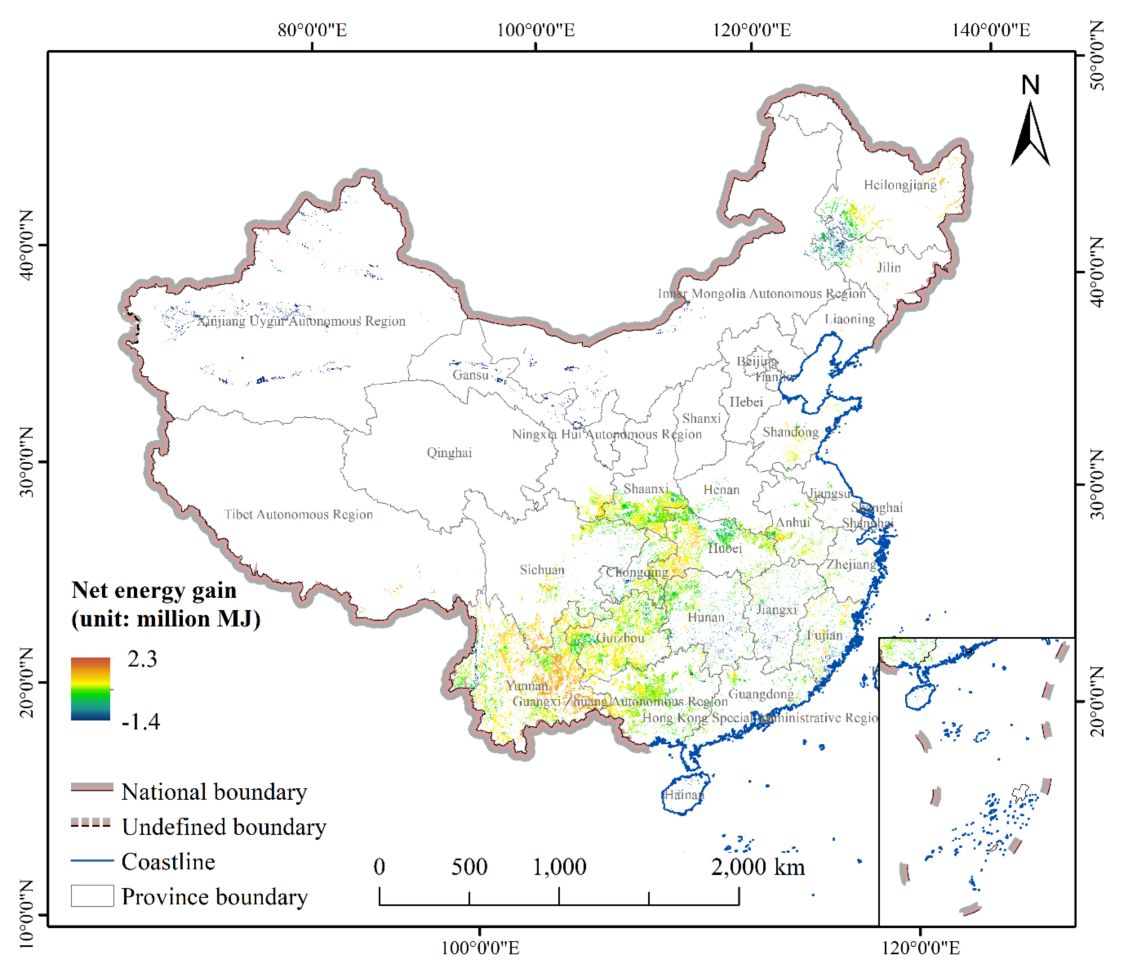

Figure 6. Spatial distribution of net energy gain of sweet sorghum-based ethanol.

According to Figure 6, net energy gain ranges from -1.4 million MJ to 2.3 million MJ per grid. High values are centralized in southern and parts of the northern part of China. The statistics of net energy gain for every province were analyzed. The bar chart is shown in Figure 7.

According to Figure 7, Yunnan Province showed the highest net energy gain, with a value of 52.84 billion MJ, followed by Guizhou Province, with a value of 25.57 billion MJ, and Hubei Province, and the Guangxi Zhuang Autonomous Region with values of 19.00 billion MJ and 17.53 billion MJ, respectively. Net energy gains in the Xinjiang Uygur Autonomous Region, Gansu and the Inner Mongolia Autonomous Region showed negative values of -8.31 billion MJ, -2.22 billion MJ, and -2.00 billion MJ, respectively. These regions got negative net energy gains mainly because the weather and soil conditions there could not satisfy the requirements of planting sweet sorghum. Thus, the amount of aboveground biomass and sweet sorghum-based ethanol were so low that the energy output of sweet sorghum-based ethanol could not cover the total energy consumptions over the life cycle of sweet sorghum-based ethanol in these regions. Overall, total net energy gain with positive values was 182.62 billion MJ per year, and total net energy gain with negative values was -17.53 million MJ per year. 


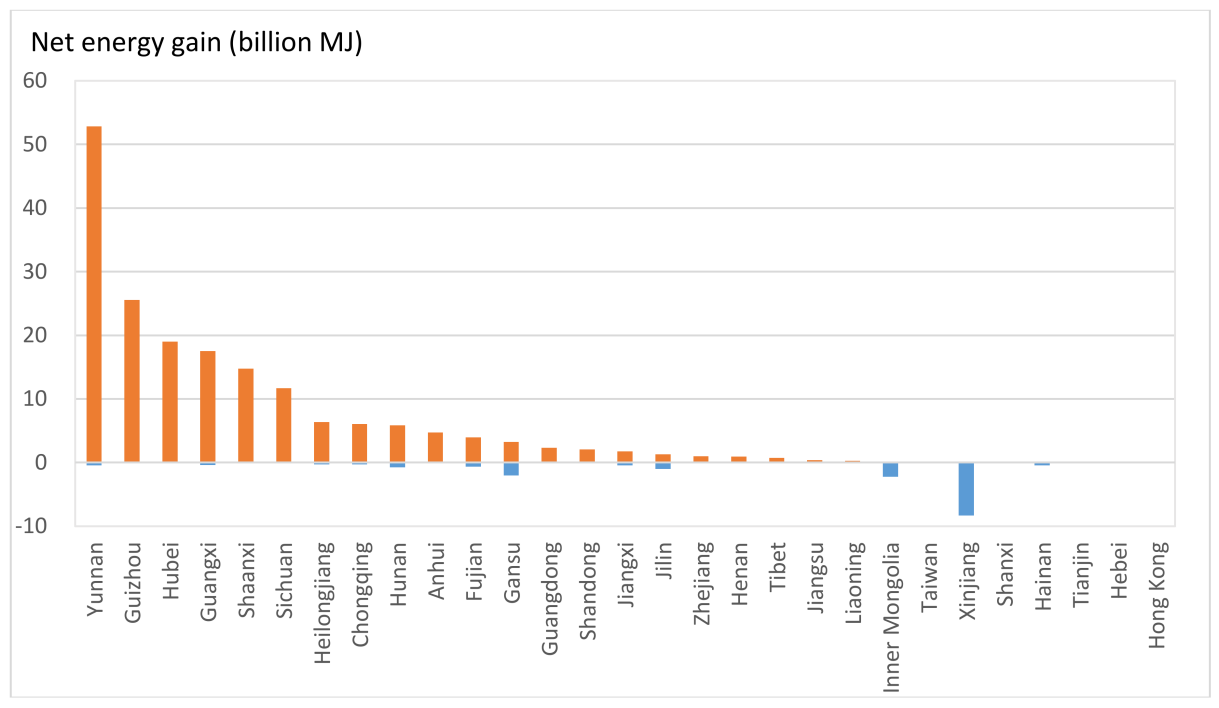

Figure 7. Statistics of net energy gain of provinces.

\subsection{Marginal Lands Suitable for Sweet Sorghum-Based Ethanol Development}

For the further assessment of GHG emissions, basins with high water stress and regions with negative net energy gain were considered unsuitable for sweet sorghum development. The suitability analysis of the marginal lands for developing sweet sorghum-based ethanol is shown in Figure 8.

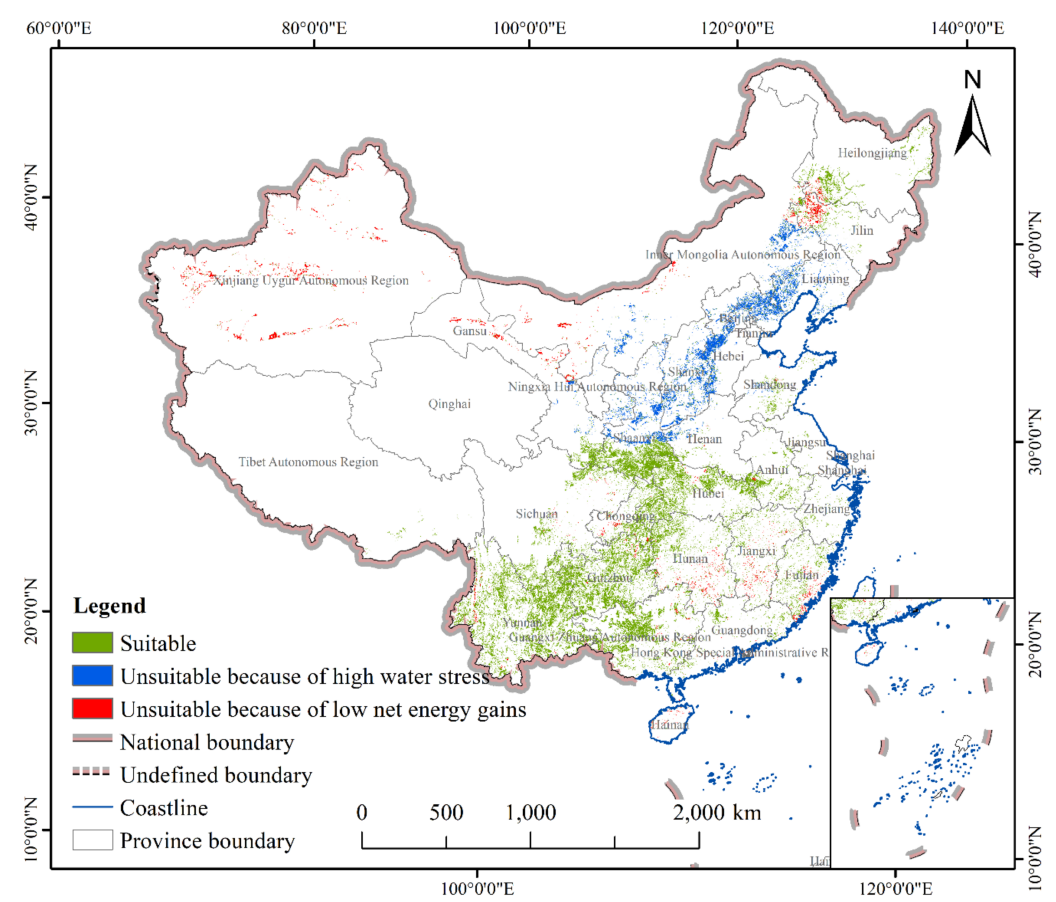

Figure 8. The suitability analysis of marginal lands for developing sweet sorghum-based ethanol.

After the suitability analysis of marginal lands for developing sweet sorghum-based ethanol, $26.72 \%$ of the marginal lands were considered unsuitable, and the remaining marginal lands which were considered suitable covered an area of $387,447.79 \mathrm{~km}^{2}$. The remaining marginal lands were centralized in southern and parts of northeastern parts of China. Water consumption and net energy gains on the marginal lands suitable for developing sweet sorghum-based ethanol was recalculated as 348.95 billion $\mathrm{m}^{3}$ and 182.62 billion MJ per year, respectively. 


\subsection{GHG Emission Assessment Result}

GHG emissions and potential GHG emissions reduction were analyzed based on the marginal lands suitable for developing sweet sorghum-based ethanol, and the potential GHG emissions reduction are shown in Figure 9.
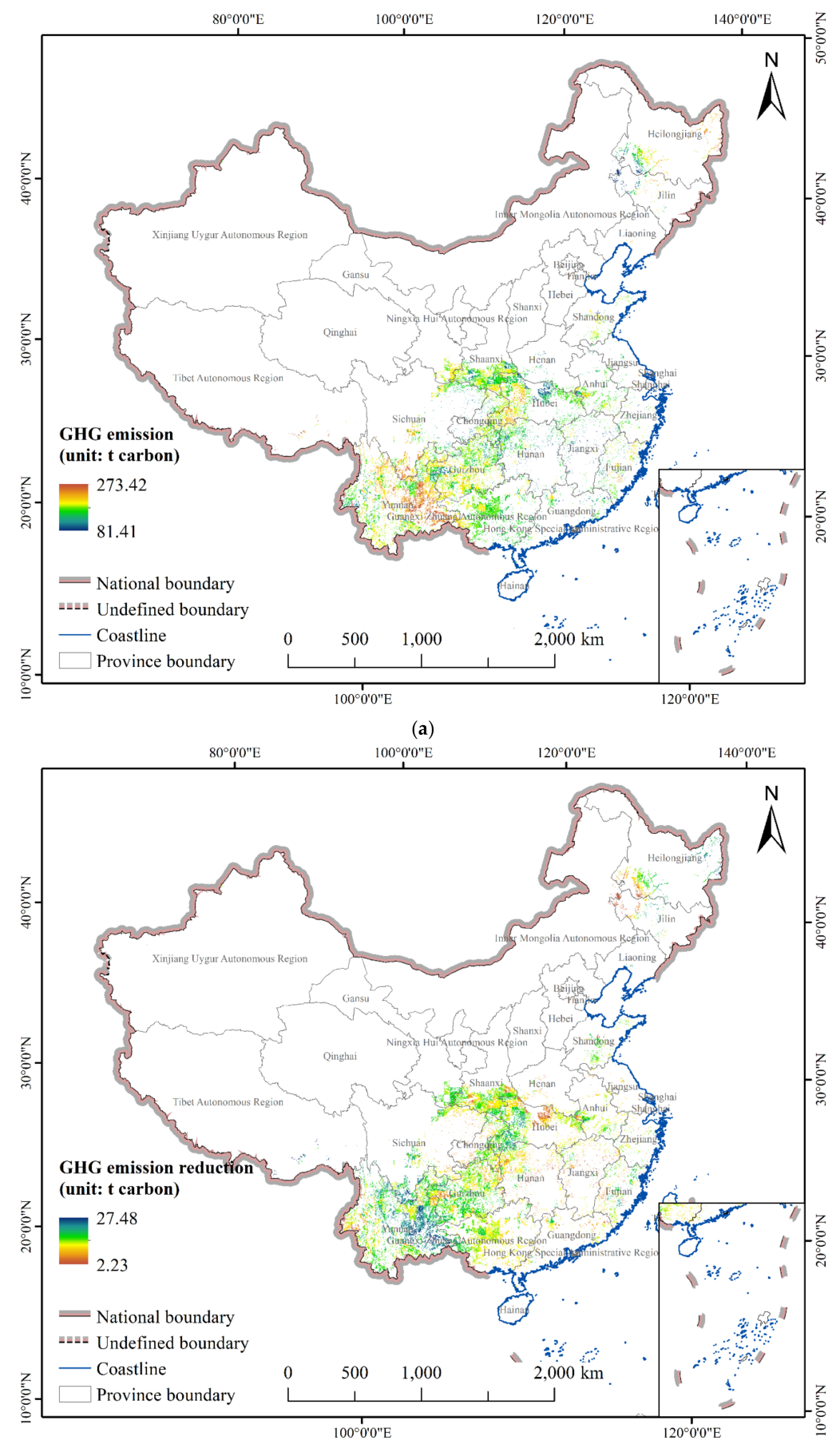

(b)

Figure 9. GHG emissions and potential GHG emissions reduction on the remaining marginal lands in China: (a) the spatial distribution of GHG emission; and (b) the spatial distribution of potential GHG emission reduction. 
According to Figure 9, the GHG emissions of sweet sorghum-based ethanol ranged from $81.41 \mathrm{t}$ Carbon to $273.42 \mathrm{t}$ Carbon, and the potential GHG emissions reduction ranged from $2.23 \mathrm{t}$ Carbon to $27.48 \mathrm{t}$ Carbon. Although, according to Section 3.3, Yunnan showed high net energy gains, it also produced the highest GHG emissions. In conclusion, developing sweet sorghum-based ethanol on marginal lands would cause 36.66 million tons of GHG emissions, and the GHG emission reduction potential would be 2.47 million tons of GHG emissions, equivalent to the GHG emissions caused by 0.86 million tons of petrol.

\section{Discussion}

\subsection{Comparison with Other Studies}

In this study, the potential of sweet sorghum-based ethanol development in China was evaluated within Water-Energy-Food nexus framework. Based on the related previous studies in this field, net energy gain and GHG emission potentials were discussed and compared with others.

Wang et al. conducted a life cycle assessment study of energy efficiency performance of bioethanol production from sweet sorghum stem in China, concluding that the net energy ratio was 1.56 and the net energy gain was $8.37 \mathrm{MJ} / \mathrm{L}$ ethanol [39]. Given that the net energy gain by Wang et al. was a standard, net energy gain in this paper should range from 0.16 million MJ to 5.93 million MJ rather than from -1.4 million MJ to 2.3 million MJ. GHG emission potential was compared with a study documented by Olukoya et al. According to Olukoya et al., GHG emissions were reduced by $27 \%$ and $15 \%$ with two different ethanol producing options [40]. In this study, GHG emission and GHG emission reduction of developing sweet sorghum-based ethanol on marginal lands were 36.66 million tons and 2.47 million tons, respectively, indicating a $6.7 \%$ decrease of GHG emissions. The net energy gain and GHG emission reduction potentials were predicted as lower than the results of Wang et al. and Olukoya et al. mainly because biomass on marginal lands was estimated in this study. Marginal lands are usually land types with severe growing conditions. Thus, it is reasonable to get lower net energy gain and GHG emission potentials in this study. Besides, this study presented the spatial distribution of net energy gain, GHG emission reduction potentials, which is more helpful for policy makers to decide which regions should be given priority for sweet sorghum-based ethanol development.

\subsection{Measures for Improving Potential Assessment}

Two aspects could be considered for a better performance of the assessment. First, the DSSAT model was calibrated by field experimental data of only one species in this paper, but, in reality, various sweet sorghum varieties are planted in different regions. However, as there are many kinds of marginal lands in China such as saline-alkali land, shrub land and spare land, one species cannot adapt to the growing environment all kinds of marginal lands. Moreover, salt content and water content of different sweet sorghum varieties varies greatly, and these ingredients have direct impact on the conversion coefficients from sweet sorghum to fuel ethanol. Thus, some potential regions may be ignored if only one species was studied. Second, a transport model should be coupled with the life cycle assessment. Currently, most studies in this field calculate the energy input and GHG emissions in transport stages using statistical data. However, sweet sorghum cultivation lands, ethanol factories and gasoline stations are spatially distributed, so energy input and GHG emissions varies from site to site. Hence, the potential assessment method could be improved through a transport model with geo-spatial analysis tools.

\section{Conclusions}

In this paper, we conduct a life cycle assessment study on the potential assessment of developing sweet sorghum-based ethanol on marginal land in China, using a life cycle assessment method coupled with the DSSAT model and GIS technology. This study is carried out under the framework of the 
Water-Energy-Food nexus, and the spatial distributions of three aspects including water consumption, GHG emission, and net energy gain potential are considered and analyzed.

As illustrated by the results, the original marginal lands for developing sweet sorghum-based ethanol is $528,735.39 \mathrm{~km}^{2}$. However, $26.72 \%$ of the original marginal lands are not moderately suitable because of biomass-water conflicts or low net energy gains. These places are mostly located in the western and northern parts of China, especially the Xinjiang Uygur Autonomous Region, the Inner Mongolia Autonomous Region, northern part of Gansu Province, and provinces of Yellow River, Hai River, and Liao River basins. The area of remaining marginal lands is $387,447.79 \mathrm{~km}^{2}$, within which provinces of the southern part of China and parts of Northeastern China show higher net energy gain potential and GHG emission reduction potentials than other regions. Among these regions, policy makers can give some priority of sweet sorghum-based ethanol development to Yunnan Province, Guangxi Zhuang Autonomous Region, Hubei Province and the southern part of Shaanxi Province, whereas the potential of Jilin Province and Heilongiiang Province needs further studies and assessment. Overall, the water consumption of sweet sorghum-based ethanol in China is predicted to be 348.95 billion $\mathrm{m}^{3}$. The net energy gain potential of the marginal lands suitable for developing sweet sorghum-based ethanol is evaluated at 182.62 billion MJ per year. The GHG emissions reduction potential on the remaining marginal lands s estimated at 2.47 million tons of carbon per year, equivalent to the GHG emissions caused by 0.86 million tons of petrol per year.

In the next study, switchgrass, cassava and other non-food energy crops should be considered for the assessment of non-food bio-ethanol development potential in China within Water-Energy-Food nexus frameworks.

Acknowledgments: The work was supported by National Natural Science Foundation of China (grant numbers 41601589); and Institute of Geographical Sciences and Natural Resources Research (grant number 2016RC203).

Author Contributions: Xiaoxi Yan, Jingying Fu and Dong Jiang conceived and designed the study; Xiaoxi Yan and Jingying Fu analyzed the data; Mengmeng Hao contributed materials and analysis tools; and Xiaoxi Yan wrote the paper.

Conflicts of Interest: The authors declare no conflict of interest.

\section{References}

1. Streck, C.; Unger, M.V.; Keenlyside, P. The Paris agreement: A new beginning. J. Eur. Environ. Plan. Law 2016, 13, 3-29. [CrossRef]

2. United Nations Framework Convention on Climate Change. Paris Agreement; United Nations Framework Convention on Climate Change: Paris, France, 2015.

3. Teske, S.; Lins, C.; Hullin, M.; Williamson, L.; Fattal, A. Renewables Global Futures Report: Great Debates towards 100\% Renewable Energy; REN21: Paris, France, 2017.

4. Srirangan, K.; Akawi, L.; Moo-Young, M.; Chou, C.P. Towards sustainable production of clean energy carriers from biomass resources. Appl. Energy 2012, 100, 172-186. [CrossRef]

5. Muth, D.J., Jr.; Bryden, K.M.; Nelson, R.G. Sustainable agricultural residue removal for bioenergy: A spatially comprehensive US national assessment. Appl. Energy 2013, 102, 403-417. [CrossRef]

6. BP. BP Energy Outlook, 2018 ed. Available online: https://www.bp.com/en/global/corporate/energyeconomics/energy-outlook.html (assessed on 1 March 2018).

7. Zhang, X.D.; Vesselinov, V.V. Integrated modeling approach for optimal management of water, energy and food security nexus. Adv. Water Resour. 2017, 101, 1-10. [CrossRef]

8. Vogt, K.; Patel-Weynand, T.; Shelton, M.; Vogt, D.J.; Gordon, J.C.; Mukumoto, C.; Suntana, A.S.; Roads, P.A. Sustainability Unpacked: Food, Energy and Water for Resilient Environments and Societies; Routledge: Gateshead, UK, 2012.

9. United Nations Economic and Social Commission for Asia (UNESCAP). The Status of the Water-Food-Energy Nexus in Asia and the Pacific; UNESCAP: Bangkok, Thailand, 2013.

10. Chang, Y.; Li, G.J.; Yao, Y.; Zhang, L.X.; Yu, C. Quantifying the water-energy-food nexus: Current status and trends. Energies 2016, 9. [CrossRef] 
11. Andrewsspeed, P.; Bleischwitz, R.; Boersma, T.; Johnson, C.; Kemp, G.; Vandeveer, S.D. The Global Resource Nexus: The Struggles for Land, Energy, Food, Water, and Minerals; Transatlantic Academy: Washington, DC, USA, 2012.

12. Hoff, H. Understanding the Nexus. Background Paper for the Bonn2011 Conference: The Water, Energy and Food Security Nexus; SEI: Stockholm, Sweden, 2011.

13. Food and Agriculture Organization (FAO). The Water-Energy-Food Nexus: A New Approach in Support of Food Security and Sustainable Agriculture; FAO: Rome, Italy, 2014.

14. Seachinger, T.; Ralph, H. Avoiding Bioenergy Competition for Food Crops and Land; World Resources Institute: Washington, DC, USA, 2015.

15. Yimam, Y.T.; Ochsner, T.E.; Fox, G.A. Hydrologic cost-effectiveness ratio favors switchgrass production on marginal croplands over existing grasslands. PLoS ONE 2017, 12, e0181924. [CrossRef] [PubMed]

16. Hao, M.M.; Jiang, D.; Wang, J.H.; Fu, J.Y.; Huang, Y.H. Could biofuel development stress China's water resources? Gcb Bioenergy 2017, 9, 1447-1460. [CrossRef]

17. Xie, X.; Zhang, T.; Wang, L.; Huang, Z. Regional water footprints of potential biofuel production in china. Biotechnol. Biofuels 2017, 10, 95. [CrossRef] [PubMed]

18. Flammini, A.; Puri, M.; Pluschke, L.; Dubois, O. Walking the nexus talk: Assessing the water-energy-food nexus in the context of the sustainable energy for all initiative. J. Phys. Chem. A 2014, 115, 7869-7870.

19. Gosens, J.; Kåberger, T.; Wang, Y. China's next renewable energy revolution: Goals and mechanisms in the 13th five year plan for energy. Energy Sci. Eng. 2017, 5, 141-155. [CrossRef]

20. Li, S.; Li, G.; Zhang, L.; Zhou, Z.; Han, B.; Hou, W.; Wang, J.; Li, T. A demonstration study of ethanol production from sweet sorghum stems with advanced solid state fermentation technology. Appl. Energy 2013, 102, 260-265. [CrossRef]

21. Almodares, A.; Hadi, M.R.; Kholdebarin, B.; Samedani, B.; Kharazian, Z.A. The response of sweet sorghum cultivars to salt stress and accumulation of $\mathrm{Na}^{+}, \mathrm{Cl}^{-}$and $\mathrm{K}^{+}$ions in relation to salinity. J. Environ. Biol. 2014, 35, 733-739. [PubMed]

22. Zegada-Lizarazu, W.; Luna, D.F.; Monti, A. Differential characteristics of photochemical acclimation to cold in two contrasting sweet sorghum hybrids. Physiol. Plant. 2016, 157, 479-489. [CrossRef] [PubMed]

23. Reap, J.; Roman, F.; Duncan, S.; Bras, B. A survey of unresolved problems in life cycle assessment. Int. J. Life Cycle Assess. 2008, 13, 290-300. [CrossRef]

24. Houshyar, E.; Grundmann, P. Environmental impacts of energy use in wheat tillage systems: A comparative life cycle assessment (LCA) study in Iran. Energy 2017, 122, 11-24. [CrossRef]

25. International Organization for Standardization (ISO). Environmental Management-Life Cycle Assessment-Requirements and Guidelines; ISO: Geneva, Switzerland, 2006; Volume 14044.

26. Jones, J.W.; Hoogenboom, G.; Porter, C.H.; Boote, K.J.; Batchelor, W.D.; Hunt, L.A.; Wilkens, P.W.; Singh, U.; Gijsman, A.J.; Ritchie, J.T. The DSSAT cropping system model. Eur. J. Agron. 2003, 18, 235-265. [CrossRef]

27. Wang, M.; Han, J.W.; Dunn, J.B.; Cai, H.; Elgowainy, A. Well-to-wheels energy use and greenhouse gas emissions of ethanol from corn, sugarcane and cellulosic biomass for US use. Environ. Res. Lett. 2012, 7, 045905. [CrossRef]

28. Wu, M.; Wang, M.; Hong, H. Fuel-Cycle Assessment of Selected Bioethanol Production; Argonne National Laboratory: Lemont, IL, USA, 2007.

29. Burnham, A.; Wang, M.Q.; Wu, Y. Development and Applications of GREET 2.7-The Transportation Vehicle-CycleModel; Argonne National Laboratory: Lemont, IL, USA, 2006.

30. Ritchie, J.T. Model for predicting evaporation from a row crop with incomplete cover. Water Resour. Res. 1972, 8, 1204-1213. [CrossRef]

31. Fu, J. Assessment of the Non-Grain Based Fuel Ethanol Potential in China; The University of Chinese Academy of Sciences: Beijing, China, 2015.

32. Hao, M. Evaluation of Energy Saving Potential and GHG Reductionpotential of Bio-Fuel Ethanol from Cassava at Large Scale; The University of Chinese Academy of Sciences: Beijing, China, 2015.

33. Liu, L.; Zhuang, D.F.; Jiang, D.; Fu, J.Y. Assessment of the biomass energy potentials and environmental benefits of Jatropha curcas L. in Southwest China. Biomass Bioenergy 2013, 56, 342-350. [CrossRef]

34. Zhang, F.L.; Johnson, D.M.; Wang, J.J. Life-cycle energy and GHG emissions of forest biomass harvest and transport for biofuel production in Michigan. Energies 2015, 8, 3258-3271. [CrossRef]

35. Fu, J.; Dong, J.; Huang, Y.; Zhuang, D.; Wei, J. Evaluating the marginal land resources suitable for developing bioenergy in Asia. Adv. Meteorol. 2014, 2014, 45-49. [CrossRef] 
36. Jiang, D.; Hao, M.; Fu, J.; Zhuang, D.; Huang, Y. Spatial-temporal variation of marginal land suitable for energy plants from 1990 to 2010 in China. Sci. Rep. 2014, 4, 5816. [CrossRef] [PubMed]

37. Hoogenboom, G.; Porter, C.H.; Shelia, V.; Boote, K.J.; Singh, U.; White, J.W.; Hunt, L.A.; Ogoshi, R.; Lizaso, J.I.; Koo, J.; et al. Decision Support System for Agrotechnology Transfer (DSSAT) Version 4.7. Available online: https: / DSSAT.net (accessed on 2 November 2017).

38. Hutchinson, M.F.; Xu, T. Anusplin Version 4.2 User Guide; Centre for Resource and Environmental Studies, The Australian National University: Canberra, Australia, 2004.

39. Wang, M.; Chen, Y.; Xia, X.; Li, J.; Liu, J. Energy efficiency and environmental performance of bioethanol production from sweet sorghum stem based on life cycle analysis. Bioresour. Technol. 2014, 163, 74-81. [CrossRef] [PubMed]

40. Olukoya, I.A.; Bellmer, D.; Whiteley, J.R.; Aichele, C.P. Evaluation of the environmental impacts of ethanol production from sweet sorghum. Energy Sustain. Dev. 2015, 24, 1-8. [CrossRef]

(C) 2018 by the authors. Licensee MDPI, Basel, Switzerland. This article is an open access article distributed under the terms and conditions of the Creative Commons Attribution (CC BY) license (http://creativecommons.org/licenses/by/4.0/). 